\title{
Geometric Aspects of Number Line Estimations*
}

\begin{tabular}{ccc}
\hline Article Type & Received Date & Accepted Date \\
Research & 15.09 .2018 & 29.12 .2018 \\
\hline
\end{tabular}

Sinan Olkun ${ }^{* *}$

\author{
Mehmet Hayri Sari***
}

Glenn Gordon Smith*****

\begin{abstract}
Number lines are implicitly embedded in nature. Yet researchers use them for measuring number sense as if they are processed purely through numerical reasoning. We argue that number line estimation tasks are done both by numerical and geometric reasoning. The purpose of this research was to investigate the relationships among mathematics achievement, geometry achievement, spatial skills, and number line estimations. A total of 142 fourth graders were administered 5 different tests: 2 curriculum-based math achievement tests, a spatial visualization test, a number line estimation test, and the Raven Standard Progresive Matrices test. Results showed; estimation accuracy of the relative magnitude of numbers on an empty number line has more to do with geometry achievement and diagrammatic reasoning rather than with numerical or arithmetic reasoning. It seems that number line estimation tasks may constitute an interplay between number and shape. Therefore, we conclude that using multiple external representations of numbers, such as spatial, symbolic, and verbal could be useful in developing a more robust number sense.
\end{abstract}

Keywords: Number line estimations, numerical reasoning, geometric reasoning, number sense.

\footnotetext{
${ }^{*}$ An earlier version of this paper has been presented in $13^{\text {th }}$ International Congress on Mathematical Education, July 24-31 2016, Hamburg, Germany.

*** Corresponding Author: Assist. Prof. Dr., Nevşehir Hacı Bektaş Veli University, Faculty of Education, Department of Primary Education, Nevşehir, Turkey. E-mail: mhsari@nevsehir.edu.tr, https://orcid.org/0000-0002-7159-2635

** Prof. Dr., Final International University, Faculty of Education, Department of Science and Mathematics Education, Girne, Cyprus. E-mail: sinan.olkun@ fiu.edu.tr, https://orcid.org/0000-0003-3764-2528

* Prof. Dr., University of South Florida, Faculty Instructional Technology Program, Department of Educational \& Psychological Studies, Florida, USA. E-mail: glenns@usf.edu, https://orcid.org/0000-0003-1506-9484
} 


\title{
Sayı Doğrusu Tahmin Becerisinin Geometrik Yönü*
}

\begin{tabular}{ccc}
\hline Makale Türü & Başvuru Tarihi & Kabul Tarihi \\
Araştırma & 15.09 .2018 & 29.12 .2018 \\
\hline
\end{tabular}

\author{
Sinan Olkun $^{* *} \quad$ Mehmet Hayri Sarı ${ }^{* * *} \quad$ Glenn Gordon Smith ${ }^{* * * *}$ \\ Öz
}

Sayı doğrusu doğal ortamlarda kendiliğinden vardır. Fakat araştırmacılar sayı doğrusu tahmin görevlerini genellikle saf sayısal becerileri ölçmek amacıyla kullanmaktadırlar. Biz ise sayı doğrusunda tahmin görevlerinin hem sayısal hem de geometrik akıl yürütme gerektirdiğini savunmaktayız. $\mathrm{Bu}$ araştırmanın amacı matematik başarısı, geometri başarısı, uzamsal beceriler ve sayı doğrusu tahminleri arasındaki ilişkiyi incelemektir. Toplam 142 dördüncü sınıf öğrencisine 5 farklı test uygulanmıştır: Bunların ikisi müfredata dayalı matematik başarı testidir. Ayrıca uzamsal görselleştirme testi, sayı doğrusu tahmin testi ve Raven Progresif Matrisler testi araştırmanın veri toplama araçlarını oluşturmaktadır. Verilerin analizinde Pearson korelasyon katsayısı, regresyon analizi ve bağımsız örneklemler t-testi analizi kullanılmıştır. Elde edilen bulgulara göre; boş bir sayı doğrusunda sayıların göreceli büyüklüğünün tahmin doğruluğu, aritmetikten ziyade geometri başarısı ve şematik akıl yürütme ile daha fazla ilgili olduğu ortaya konulmuştur. Sayı doğrusunda tahmin görevleri şekil ve sayı kavramları için ortak bir alan oluşturmaktadır. Bu nedenle, uzamsal, sembolik ve sözel gibi sayıların çoklu temsilini kullanmak daha sağlam bir sayı hissinin geliştirilmesinde yararlı olabilir.

Anahtar Sözcükler: Sayı doğrusu tahmini, sayısal akıl yürütme, geometrik akıl yürütme, sayı hissi.

\footnotetext{
* Bu çalışma 24-31 Temmuz 2016 tarihlerinde Hamburg'da düzenlenen 13. Uluslararası Matematik Eğitimi Kongresinde sözlü bildiri olarak sunulmuştur.

*** Sorumlu yazar: Dr. Öğr. Üyesi., Nevşehir Hacı Bektaş Veli Üniversitesi, Eğitim Fakültesi, Temel Eğitim Bölümü,

Nevşehir, Türkiye. E-posta: mhsari@nevsehir.edu.tr, https://orcid.org/0000-0002-7159-2635

** Prof. Dr., Uluslararası Final Universitesi, Eğitim Fakültesi, Matematik ve Fen Bilimleri Eğitimi Bölümü, Girne, Kıbrıs. E-posta: sinan.olkun@ fiu.edu.tr, https://orcid.org/0000-0003-3764-2528

***** Prof. Dr., South Florida Üniversitesi, Öğretim Teknolojileri Fakültesi, Eğitim ve Psikoloji Çalışmaları Fakültesi, Florida, USA. E-posta: glenns@usf.edu, https://orcid.org/0000-0003-1506-9484
} 


\section{Introduction}

Measuring students' mathematical abilities are important and valuable task both psychologically and educationally. Yet instead of focusing on complex mathematical tasks, recent research has focused on very simple tasks to measure core abilities that seem to be closely related to mathematics learning and achievement. The results are very promising in showing that efficiencies in these simple tasks predict an important portion of mathematics scores as well as future mathematics achievement.

The motivation behind these approaches is the theory that human cognition consists of a small number of separable units for processing knowledge (Spelke \& Kinzler, 2007). These units are objects, actions, numbers, space, and possibly social partners. Some evidence from brain research also supports this position (Dehaene, Molko, Cohen, \& Wilson, 2004). This paper focuses on the relationship between number systems and spatial processing.

Some researchers (Spelke \& Kinzler, 2007) believe that, in the human brain, there are two separate modules for number and space residing in different areas of the brain, but interacting with each other (Olkun \& Denizli, 2015; Verdine, Golinkoff, Hirsh-Pasek, \& Newcombe, 2014). Up to now, four subsystems or aspects of the number module have been claimed (Butterworth, 2010; Feigenson, Dehaene, \& Spelke, 2004; Izard, Pica, Spelke, \& Dehaene, 2008; Olkun, Altun, \& Göçer Şahin, 2015). Tasks used to measure the function of these subsystems have also been developed and used in research studies to investigate their relationships with mathematics achievement.

The first subsystem in the number module is the Exact Number System (ENS) (Izard et al., 2008). Subitizing and exact calculations are supposed to be based on ENS. There is ample evidence that infants can make numerical judgments starting a few days after birth (Antell \& Keating, 1983) through an object-based quantifier system, called subitizing, a rapid enumeration of quantities up to 3 or 4 . The functioning of this system is measured through dot enumeration paradigms. Subjects are shown a number of dots and asked to immediately say their number as quickly as possible. The learning of counting and calculation is related to ENS.

The second system, Access to Symbols (ATS), is used to associate symbols to quantities and vice versa. The numerical Stroop tasks or symbolic number comparison tasks are used in measuring the functioning of this subsystem (Girelli, Lucangeli, \& Butterworth, 2000), but symbols such as Arabic numerals, are also used in many of the tasks designed for measuring numerical abilities. Although, these subsystems may not be completely dissociable through behavioral tasks, the patterns of efficiency might be an indicator for the independent functioning of certain subsystems.

The third system, numerosity coding (Butterworth, 2010; Olkun, Altun, \& Göçer Şahin, 2015), is an inherited system for sets of objects and operations on them, on which arithmetic is built. Any dysfunction in numerosity coding, not in the approximate number system or the small number system, results in dyscalculia (Butterworth, 2010). However, this system seems to be built on the Exact Number System, possibly with some input from the Approximate Number System.

The fourth subsystem, assumed to be present in human brain is the Approximate Number System (ANS). This is an evolutionary ancient system for processing approximate quantities that human beings share with other animals. Other mathematical abilities are built on the Approximate Number System (Dehaene, 2009). Some researchers claim that the ANS is the only core system and all the other arithmetical abilities are built on this system. The functioning of ANS is measured through estimation (Siegler \& Booth, 2005) or quantity comparison (Lemer, Dehaene, Spelke, \& Cohen, 2003) tasks.

Estimation or reasoning with approximate quantities is an important process in mathematics education. According to Siegler and Booth (2005) many types of estimations require going beyond the rote application of procedures and applying mathematical knowledge in flexible ways. In contrast to exact calculations, estimation enables people to get a quicker and more informed answer. Siegler and Booth (2005) defined estimation "as a process of translating between alternative quantitative representations, at least one of which is inexact" (p.198) and listed several estimation types one of which is number line estimation. 
Number line estimations involve the evaluation of spatial representations of numerical magnitudes. Number line estimations involve for instance finding the relative position of an Arabic number on a number line, or plotting a number on a number line. Typically, a number line shows zero on the left and 10-100 or 1000 on the right. Accuracy in spatial representation of number magnitude is a reliable predictor of current and future arithmetic abilities (Booth \& Siegler, 2006; Link, Moeller, Huber, Fischer, \& Nuerk, 2013; Siegler \& Booth, 2004). Therefore, number line estimation is considered a basic skill that lays the foundations for broader mathematical abilities (Sasanguie, Gobel, Moll, Smets, \& Reynvoet, 2013).

It has been shown, especially in the last ten years, that the ability to accurately estimate the relative location of numbers on a number line is strongly related to important skills in mathematics, such as estimation, computational estimation as well as performance on standard mathematics achievement tests (Lefevre et al., 2013). Accuracy in number line estimations is related to arithmetic, number comparisons, and individual differences in general mathematics achievement (Booth \& Siegler, 2006; Laski \& Siegler, 2007; Sasanguie, Smedt, Defever, \& Reynvoet, 2011; Sasanguie et al., 2013), as well as spatial skills (Lefevre et al., 2013). Which process or processes mediate to these relationships remains an important question to answer. This research can inform the teaching of number sense to children, and help them to be more efficient mathematics learners (Schneider, Grabner, \& Paetsch, 2009).

Conversely, a major requirement for performing number line tasks is some spatial ability and spatial skill (Gunderson, Ramirez, Beilock \& Levine, 2012). In other words, spatial skills can help students make better number line estimations especially in the early years of formal schooling (Gunderson et al., 2012).

In sum, it seems that number line estimations are strong predictors of basic mathematical performance. On the other hand, it also seems that accuracy in estimations might be supported by one's spatial skills. This study will investigate the relationships between: (1) the geometric performance and (2) arithmetic performance and, (3) accuracy in number line estimations.

\section{Method}

\section{Research Design}

This study used a relational survey design. The relationships between students' number line estimations, and their spatial skills, geometry, arithmetic and mathematics achievement scores were investigated.

\section{Study Group}

To achieve maximum diversity within our sample including a wide range of socioeconomic strata (Büyüköztürk, Çakmak, Akgün, Karadeniz \& Demirel, 2008), 142 fourth graders were selected from a school that accommodates a wide range of sociocultural backgrounds. The mean age of the participants was 9.5 years. There were approximately an equal numbers of boys $(n=68)$ and girls $(\mathrm{n}=74)$ in the study, with quite similar mean ages ( 9.2 for boys and 9.6 for girls).

\section{Research Instruments and Procedures}

Participants took five different tests: two curriculum-based math achievement tests, one focusing on numbers called Mathematics Achievement Test (MAT) and the other involving geometry tasks called Geometry Achievement Test (GAT), a spatial visualization test (SVT), the Number Line estimation Test (NLT), and a test on discerning visual patterns, the Raven Standard Progressive Matrices Test (RSPMT).

Mathematics Achievement Test: The Mathematics Achievement Test (MAT) was developed by Fidan (2013) for grades 1-4, based on the number domain section of the Turkish National Education math curriculum. It includes numbers, counting, number patterns, four arithmetic operations, and fractions. The KR-20 coefficients of the MAT test were .80 for first graders, .92 for second graders, .93 for third graders, and .96 for the fourth graders. The administration of the test took one hour of class time. 
The Geometry Achievement Test (GAT) was developed by Olkun, Akkurt-Denizli, Kozan, and Ayyldiz (2013) based on math curriculum and includes questions from geometry and measurement domains of the Turkish National Curriculum (MEB, 2004). There are questions related to naming and measuring some aspects of two- and three-dimensional geometric shapes. The internal consistency of the test was 0.91 as measured by KR-20. The suggested time for the test is 40 minutes.

The Spatial Visualization Test (SVT) was developed by Olkun (2003). The test has 29 items in 4 sections: spatial, spatio-numeric, mental rotation, and informal area measurement. The internal consistency of the test was 0.78 as measured by KR-20 test. As suggested by the authors of the test, students were given 40 minutes to complete the test.

In the Mental Number Line (MNL) test, developed by Olkun, Altun, Göçer Şahin, \& Akkurt Denizli (2015), students place numbers shown one at a time on the number line by drawing a hash mark on the number line (see Figure $1 \mathrm{a} \& \mathrm{~b}$ ). No timing is recorded for this test. Only the absolute values of the differences between the student estimations and the actual correct positions of numbers are recorded. There were a total of 58 items in MNL tests, 18 items in MNL 1, and 40 items in MNL 2. The numbers used for the MNL 1 (0-10) were: 4, 2, 8, 1, 7, 3, 2, 5, 9, 7, 4, 9, 6, 3, 5, 8, 6, 1, and for the MNL 2 (0-100) 81, 50, 66, 90, 96, 30, 8, 40, 14, 50, 35, 59, 72, 33, 21, 79, 24, 84, 4, 75, 3, 57, 48, $12,6,17,25,80,61,20,75,25,52,88,10,70,39,60,42,97$. There were 2 practice items, one before each of the actual test ( 2 for MNL1, and 68 for MNL 2).

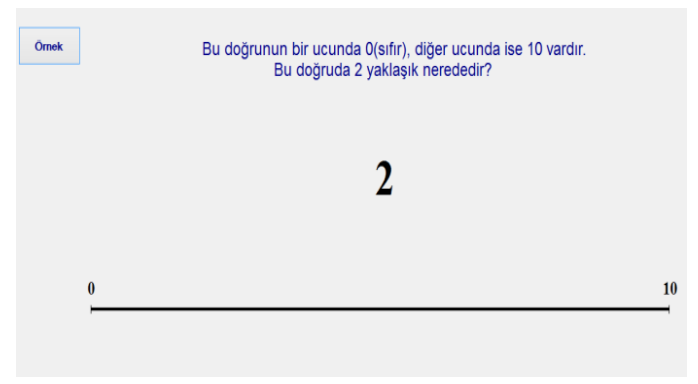

(a)

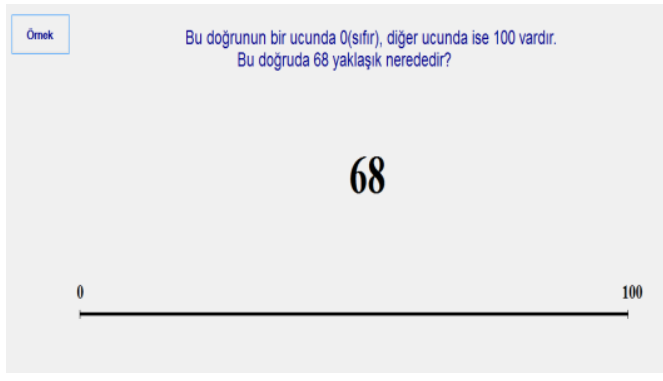

(b)

Figure 1. Sample items from the $M N L 1$ and $M N L 2$

In the Raven Standard Progressive Matrices Test (RSPMT), participants view a short sequence of shapes, and pick a shape to fill in a missing part of the sequence. RSPMT has 5 subtests each of which has 12 items.

\section{Data Analysis}

The row scores (i.e. the number of correct answers) were used for the tests, MAT, GAT, SVT, and RAVEN. The total absolute error (TAE) scores were calculated for the MNL 1 and 2 tests by using the formula "Estimations - to be estimated number)/scale" as suggested by Siegler and Booth (2004). Multiple regression analyses (stepwise method) were carried out in order to determine the explanatory power of spatial, geometric, arithmetic and mathematics skills on number line estimation accuracies. Correlations among the test scores were also calculated before the regression analysis. We also compared male and female students' scores on MAT, GAT, SVT, and RSPMT test through Independent-Samples T-tests.

\section{Results}

Before analyzing the explanatory power of the tests used in this study on number line estimations, we calculated the correlations among the tests. Results are depicted in Table 1. 


\section{Table 1}

Correlations among the Tests Used in the Study

\begin{tabular}{lllllllll}
\hline & RSPMT & ST & SNT & MRT & SMT & SVT & MNL1 & MNL2 \\
\hline GAT & $.621(* *)$ & $.387(* *)$ & $.413(* *)$ & $.179(*)$ & $.503(* *)$ & $.544(* *)$ & $-.450(* *)$ & $-.537(* *)$ \\
MAT & $.528(* *)$ & $.342(* *)$ & $.353(* *)$ & .059 & $.499(* *)$ & $.465(* *)$ & $-.317(* *)$ & $-.476(* *)$ \\
\hline
\end{tabular}

GAT: Geometry Achievement Test, MAT: Mathematics Achievement Test, RSPMT: Raven Standard Progressive Matrices Test, ST: Spatial Test, SNT: Spatio-Numeric Test, MRT: Mental Rotation Test, SMT: Spatio-Measurement Test, SVT: Spatial Visualization Test, MNL1: Mental Number Line 0-10, MNL2: Mental Number Line 0-100.

There were statistically significant correlations among all the tests used for the study, except the MRT subset of SVT and MAT. As seen from Table 1, the tests including RSPMT, MNL1 and MNL2, have stronger correlations with GAT than MAT. That means that the type of reasoning required for these tests (RSPMT visual pattern comprehension, and MNL1 and MNL2 involving number lines) had more to do with elementary geometry than with arithmetic or word problem solving.

To determine the explanatory power of spatial skills, geometry achievement (GAT), mathematics achievement (MAT), and visual pattern comprehension (RSPMT) on the accuracy of number line estimations, multiple regression analyses (stepwise method) were carried out. Table 2 depicts the summary of regression results for MNL1, RSPMT, and GAT.

Table 2

Summary of Regression Results for MNL1 with RSPMT and GAT

\begin{tabular}{rlllcccc}
\hline Model & Variables & \multicolumn{1}{c}{$\mathbf{R}$} & $\mathbf{R}^{2}$ & $\mathbf{F}$ & $\boldsymbol{\beta}$ & $\mathbf{t}$ & $\mathbf{p}$ \\
\hline 1 & RSPMT & $.465(\mathrm{a})$ & .216 & 38.58 & -.465 & -6.21 & .000 \\
& RSPMT & & & & -.302 & -3.24 & .001 \\
2 & GAT & $.508(\mathrm{~b})$ & .258 & 24.18 & -.262 & -2.80 & .006 \\
\hline
\end{tabular}

a Predictors: (Constant), RPMT (Raven Progressive Matris Test)

b Predictors: (Constant), RPMT, GAT (Raven Progressive Matrices \& Geometry Achievement Test)

When MAT, SVT, GAT and RSPMT were entered stepwise in the regression, we saw that only GAT and RSPMT had significant explanatory power on the MNL1. As seen in Table 2, RSPMT alone accounted for $\left(\mathrm{R}^{2}\right) 22 \%$ of the variance in the MNL1 test. Total accounted for variance reached $26 \%$ when we added the GAT into the analysis. It is worth noting that all the tasks in the RSPMT test have figures that require nonverbal visual reasoning.

\section{Table 3}

Summary of Regression Results for MNL1 with GAT and SVT

\begin{tabular}{clcccccc}
\hline Model & Variables & $\mathbf{R}$ & $\mathbf{R}^{2}$ & $\mathbf{F}$ & $\boldsymbol{\beta}$ & $\mathbf{t}$ & $\mathbf{p}$ \\
\hline 1 & GAT & $.450(\mathrm{a})$ & .202 & 35.46 & -.450 & -5.95 & .000 \\
& GAT & & & & -.352 & -3.96 & .000 \\
& SVT & $.474(\mathrm{~b})$ & .225 & 20.15 & -.179 & -2.01 & .046 \\
\hline
\end{tabular}

a Predictors: (Constant), GAT (Geometry Achievement Test)

b Predictors: (Constant), GAT, SVT (Geometry Achievement Test \& Spatial Visualization Test)

As presented in Table 3, GAT and SVT had significant explanatory power for the MNL1 test. GAT alone accounted for $20 \%$ of the variance in the MNL1 test. The total accounted variance reached $22 \%$, when we added the SVT into the analysis. The results also show that when we exclude GAT from the analysis, SVT alone accounted for $14 \%$ of the variance in the MNL1 test. When we add SVT and MAT stepwise into the regression, while SVT alone accounted for $14 \%$ of the variance in MNL1, total accounted variance reached $16 \%$ when we added the MAT into the analysis. MAT contributed 
only $\% 2$ to the variance (see Table 4). On the other hand, when we add GAT and MAT stepwise into the analysis, there was no change in the variance in MNL 1. In other words, MAT has no contribution to MNL1.

\section{Table 4}

Summary of Regression Results for MNL1 with SVT and MBT

\begin{tabular}{clcccccc}
\hline Model & Variables & \multicolumn{1}{c}{$\mathbf{R}$} & $\mathbf{R}^{2}$ & $\mathbf{F}$ & $\boldsymbol{\beta}$ & $\mathbf{t}$ & $\mathbf{p}$ \\
\hline \multirow{2}{*}{1} & SVT & $.371(\mathrm{a})$ & .137 & 22.31 & -.371 & -4.72 & .000 \\
& & & & & -.285 & -3.25 & .000 \\
2 & SVT & $.405(\mathrm{~b})$ & .164 & 13.64 & -.184 & -2.10 & .037 \\
\hline
\end{tabular}

a Predictors: (Constant), SVT (Spatial Visualization Test)

b Predictors: (Constant), SVT, MAT (Spatial Visualization Test \& Mathematics Achievement Test)

If we look at the findings in Table 2, Table 3, and Table 4 altogether, we can see that GAT and the other spatial tests have more explanatory power on number line estimations. When the four tests were included in regression analysis, only RSPMT and GAT had significant explanatory power on MNL1 test. RSPMT is a purely visual test. GAT also has more visual content than MAT. MAT, which focuses more on non-visual arithmetic skills, had relatively less contribution to MNL1.

We also ran a stepwise regression analysis for determining the explanatory power of RSPMT, GAT, MAT, and SVT on MNL2. Summary of the findings are depicted in Table 5.

\section{Table 5}

Summary of Regression Results for MNL2 with RSPMT and GAT

\begin{tabular}{|c|c|c|c|c|c|c|c|}
\hline Model & Variables & $\mathbf{R}$ & $\overline{\mathbf{R}^{2}}$ & $\mathbf{F}$ & $\bar{\beta}$ & $t$ & $\mathbf{p}$ \\
\hline 1 & GAT & $.537(a)$ & .288 & 56.62 & -.537 & -7.52 & .000 \\
\hline \multirow{2}{*}{2} & GAT & \multirow{2}{*}{$.580(b)$} & \multirow{2}{*}{.336} & \multirow{2}{*}{35.17} & -.363 & -4.11 & .000 \\
\hline & RSPMT & & & & -.280 & -3.17 & .002 \\
\hline
\end{tabular}

In all of the tests, only GAT and RSPMT had significant explanatory power on MNL2. The results showed that GAT alone explained 29\% of the variance in MNL2 tests scores. When we added the RSPMT into the analysis, the accounted variance reached $34 \%$. When we put GAT and MAT into the regression equation, we see that MAT has no contribution to MNL estimations in $0-100$ number line.

We also investigated whether any gender differences existed. As seen in Table 6, there are gender differences in the spatial tests favoring boys. Boys consistently did better in both spatial tests, as well as in estimating the relative magnitude of numbers on an external number line.

\section{Table 6}

Gender Differences

\begin{tabular}{lcccccc}
\hline & N & ST Mean & MRT Mean & SVT Mean & 0-10 NL TAE & 0-100 NL TAE \\
\hline Boys & 68 & 5.74 & 3.43 & 13.88 & 24.60 & 318.42 \\
Girls & 74 & 4.87 & 1.68 & 11.70 & 30.13 & 412.49 \\
& $p$ & $(.005)$ & $(.035)$ & $(.011)$ & $(.055)$ & $(.28)$ \\
\hline
\end{tabular}

ST: Spatial Test, MRT: Mental Rotation Test, SVT: Spatial Visualization Test, NL: Number Line 


\section{Discussion, Conclusion and Recommendations}

Many studies in the research literature have showed that number line estimations are strong predictor of mathematics achievement. However, we still do not understand how number line estimations relate to mathematics achievement. We hypothesize that, at least initially, number line estimations involve more spatial reasoning than numerical reasoning. For example, magnitudes are perceived as spatial magnitudes. In order to shed more light on this issue, we administered a geometry achievement test, a mathematics achievement test, two number line estimation tests and the Raven Standard Progressive Matrices Test to 142 students at the beginning of fourth grade. Analysis of the data revealed four main results:

First of all, spatial tests such as geometry (GAT) and spatial visualization (SVT) correlated more strongly with the number line estimation tasks than the other tests did. Secondly, boys did significantly better than girls did on all of the spatial tests. Third, boys also did better, made more accurate number line estimations, than did girls. Fourth, tests with relatively more spatial content have more explanatory power on number line estimation tasks. Taken together, all these results suggest that number line estimation tasks have more to do with spatial skills rather than with numerical skills. The ability to estimate the relative magnitude of numbers on an external number line may still show the power of one's number sense; however, it should be noted that these numerical skills, associated with number lines, are built on spatial processes.

These findings are consistent with Lefevre et al. (2013) and Gunderson, Ramirez, Beilock, \& Levine (2012). Lefevre et al. (2013) hypothesized that spatial skills play an important and critical role in the development of sound numerical reasoning by helping children create a spatially meaningful, powerful numerical representation, i.e., the linear number line. A strong linear number representation, in turn, improves the learning of other aspects of numerical knowledge such as arithmetic and estimation (Lefevre et al., 2013). Similarly, Gunderson et al. (2012) claimed that spatial skills help children develop the linearity in their number line estimations so that they have a better number sense. In other words, spatial skills are useful in developing a more robust number representation. Therefore, number line activities are considered very basic mathematical tools in helping children represent numbers in coordinate planes in geometry, algebra, and in many other domains of mathematics (Geary, Hoard, Nugent, \& Byrd-Craven, 2008).

Cipora, Patro, and Nuerk (2015) discussed in depth the role of spatial/numerical skills in learning arithmetic and claimed that correlations between arithmetic and spatial numerical associations are rather weak. However, they asserted that space-based interventions involving numbers might neverthe-less be helpful, since space is a powerful tool for understanding certain arithmetic concepts such as quantity and increases in quantities, etc. In fact, it seems that humans' internal as well as external representations of numbers are both spatial in nature (Gunderson et al., 2012). Similarly, Ansari et al. (2003) observed that visuospatial ability plays a greater role than language ability in the development of the understanding of cardinality in typically developing children. However, the opposite is true for the clinical group. This means that children with MLD may use different brain mechanisms for dealing with numerical situations than do typical children. They may lack the spatial thinking tools to contribute to their numerical understanding.

These findings suggest that number and space systems interact with each other as fourth graders perform mathematical tasks. In other words, the most important factor in Number Line estimations seems to be geometric skills. Further research, especially brain-based research, is needed to confirm this finding. Number line tasks are widely used in measuring number sense. Considering the spatial aspects of number sense, we recommend that spatial representations of number magnitudes can and should be used in developing a more functional number sense in children. Instructionally, using multiple, external representations of numbers, such as spatial, symbolic, and verbal, seems useful in developing more robust number sense in children. 


\section{References}

Ansari, D., Donlan, C., Thomas, M. S. C., Ewing, S. A., Peen, T., \& Karmiloff-Smith, A. (2003). What makes counting count? Verbal and visuo-spatial contributions to typical and atypical number development. Journal of Experimental Child Psychology, 85(1), 50-62. doi:10.1016/s0022-0965(03)00026-2

Antell, S. E., \& Keating, D. P. (1983). Perceptions of numerical invariance in neonates. Child Development (54), 695-701.

Booth, J. L., \& Siegler, R. S. (2006). Developmental and individual differences in pure numerical estimation. Dev Psychol, 42(1), 189-201. doi:10.1037/0012-1649.41.6.189

Butterworth, B. (2010). Foundational numerical capacities and the origins of dyscalculia. Trends in Cognitive Sciences, 14(12), 534-541. doi:10.1016/j.tics.2010.09.007

Büyüköztürk, Ş., Çakmak, E.K., Akgün, Ö.E., Karadeniz, Ş., \& Demirel, F. (2008). Bilimsel araştırma yöntemleri (4. bs.) [Scientific research methods]. (4 ${ }^{\text {th }}$ ed.) Ankara: Pegem A Publishing.

Cipora, K., Patro, K., \& Nuerk, H.-C. (2015). Are spatial-numerical associations a cornerstone for arithmetic learning? The lack of genuine correlations suggests no. Mind Brain and Education, 9(4), 190-206.

Dehaene, S. (2009). Origins of mathematical intuitions. Annals of the New York Academy of Sciences, 1156(1), 232-259. doi:10.1111/j.1749-6632.2009.04469.x

Dehaene, S., Molko, N., Cohen, L., \& Wilson, A. J. (2004). Arithmetic and the brain. Current Opinion in Neurobiology, 14(2), 218-224. doi:10.1016/j.conb.2004.03.008

Feigenson, L., Dehaene, S., \& Spelke, E. (2004). Core systems of number. Trends in Cognitive Sciences, 8(7), 307-314. doi:10.1016/j.tics.2004.05.002

Fidan, E. (2013). Illkokul ögrrencileri için matematik dersi sayılar öğrenme alanında başarı testi gelisstirilmesi [Development of achievement tests in the number domain of mathematics course for elementary school students]. (Unpublished Master Thesis), Ankara University, Institute of Educational Sciences, Ankara.

Geary, D. C., Hoard, M. K., Nugent, L., \& Byrd-Craven, J. (2008). Development of number line representations in children with mathematical learning disability. Developmental Neuropsychology, 33(3), 277-299. doi:10.1080/87565640801982361

Girelli, L., Lucangeli, D., \& Butterworth, B. (2000). The development of automaticity in accessing number magnitude. J Exp Child Psychol, 76(2), 104-122. doi:10.1006/jecp.2000.2564

Gunderson, E. A., Ramirez, G., Beilock, S. L., \& Levine, S. C. (2012). The relation between spatial skill and early number knowledge. Developmental Psychology, 48(5), 1229-1241.

Izard, V., Pica, P., Spelke, E., \& Dehaene, S. (2008). Exact equality and successor function: two key concepts on the path towards understanding exact numbers. Philosophical Psychology, 21(4), 491-505. doi:10.1080/09515080802285354

Laski, E. V., \& Siegler, R. S. (2007). Is 27 a big number? Correlational and causal connections among numerical categorization, number line estimation, and numerical magnitude comparison. Child Development, 78(6), 1723 - 1743.

Lefevre, J. A., Jimenez Lira, C., Sowinski, C., Cankaya, O., Kamawar, D., \& Skwarchuk, S. L. (2013). Charting the role of the number line in mathematical development. Front Psychol, 4, 641. doi:10.3389/fpsyg.2013.00641

Lemer, C., Dehaene, S., Spelke, E., \& Cohen, L. (2003). Approximate quantities and exact number words: dissociable systems. Neuropsychologia, 4l(14), 1942-1958. doi:10.1016/s00283932(03)00123-4

Link, T., Moeller, K., Huber, S., Fischer, U., \& Nuerk, H.-C. (2013). Walk the number line - An embodied training of numerical concepts. Trends in Neuroscience and Education, 2(2), 74-84. doi:10.1016/j.tine.2013.06.005 
MEB. (2004). Illköğretim matematik dersi öğretim programı [Elementary mathematics curriculum]. Ankara: Milli Eğitim Basımevi.

Olkun, S. (2003). Comparing computer versus concrete manipulatives. Jl. of Computers in Mathematics and Science Teaching, 22(1), 43-56.

Olkun, S., Akkurt-Denizli, Z., Kozan, S., \& Ayyıldız, N. (2013). İlkokul öğrencileri için matematik dersi geometri ve ölçme öğrenme alanlarında başarı testi geliştirilmesi [Development of achievement test in geometry and measurement learning fields for primary school students]. In XII. National Classroom Education Education Symposium, 23-25 May 2013. Adnan Menderes University, Aydın.

Olkun, S., Altun, A., \& Göçer Şahin, S. (2015). Beyond subitizing: symbolic manipulations of numbers. International Journal of Learning, Teaching and Educational Research, 10(1), 93-103.

Olkun, S., Altun, A., Göçer Şahin, S., \& Akkurt Denizli, Z. (2015). Deficits in basic number competencies may cause low numeracy in primary school children. Education and Science, 40(177). doi:10.15390/eb.2015.3287

Olkun, S., \& Denizli, Z. A. (2015). Using basic number processing tasks in determining students with mathematics disorder risk. Dusunen Adam: The Journal of Psychiatry and Neurological Sciences, 28, 47-57. doi:10.5350/dajpn2015280105

Sasanguie, D., De Smedt, B., Defever, E., \& Reynvoet, B. (2011). Association between basic numerical abilities and mathematics achievement. British Journal of Developmental Psychology, no-no. doi:10.1111/j.2044-835X.2011.02048.X

Sasanguie, D., Gobel, S. M., Moll, K., Smets, K., \& Reynvoet, B. (2013). Approximate number sense, symbolic number processing, or number-space mappings: what underlies mathematics achievement? J Exp Child Psychol, 114(3), 418-431. doi:10.1016/j.jecp.2012.10.012

Schneider, M., Grabner, R. H., \& Paetsch, J. (2009). Mental number line, number line estimation, and mathematical achievement: Their interrelations in grades 5 and 6. Journal of Educational Psychology, 101(2), 359-372. doi:10.1037/a0013840

Siegler, R. S., \& Booth, J. L. (2004). Development of numerical estimation in young children. Child Dev, 75(2), 428-444. doi:10.1111/j.1467-8624.2004.00684.x

Siegler, R. S., \& Booth, L. (2005). Development of numerical estimation: A review. In J. I. D. Campbell (Ed.), Handbook of mathematical cognition (pp. 197-212). New York: Psychology Press.

Spelke, E. S., \& Kinzler, K. D. (2007). Core knowledge. Developmental Science, 10(1), 89-96. doi:10.1111/j.1467-7687.2007.00569.x

Verdine, B. N., Golinkoff, R. M., Hirsh-Pasek, K., \& Newcombe, N. S. (2014). Finding the missing piece: Blocks, puzzles, and shapes fuel school readiness. Trends in Neuroscience and Education, 3(1), 7-13. doi:10.1016/j.tine.2014.02.005 